Floresein'in mono-, di-, tri- ve tetrabromo derivelermin kolon kromatografisi ile ayrilmaları

Separation des derives mono-, di-, tri- et tetrabromes de la Fluorescein par chromatographic en colonne

Feyyaz ONUR* Pierre LEVILLAIN**

\title{
GiRiş
}

Eosin, floresein molekülüne dört brom atomunun bağlanması ile meydana gelen ürünün adıdır $(2,4,5$. 7 tetra bromo floresein).

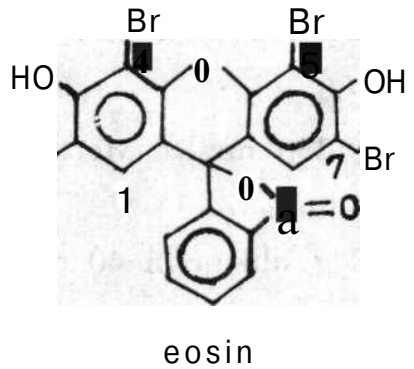

Günümüze kadar eosin sentezi üzerinde yapılan araştırmalarda eosinin saf olarak yüksek verimle elde edilmesi başarılamamıştır. Sentez sırasında eosin yanında floreseinin mono-, di- ve tribromo deriveleri de meydana gelmektedir $(1,2)$. Özellikle ticarette satılan eosinler bu deriveleri de birlikte bulundurmaktadırlar. Ayrıca 1, 2 ve 3 bromlu floresein bileşiklerinin sentezleri de çok uzun, pahalı ve çok düşük verimlidir.

Yakın senelere kadar bilinen yöntemler ile, ticarette satılan şeklinden gerek eosin gerekse diğer bromlu bileşiklerin saf olarak ayrıl-

Redaksiyona verildiği tarih: 2 Kasım 1980

* Analitik Kimya Kürsüsü, Eczacılık Fakültesi, Ankara Üniversitesi

** Laboratoire de Chimie Analytique, Faculté des Sciences Pharmaceutiques et Biologiques, 4. Avenue d'Observatoire 75006 Paris 
maları mümkün olamamıştır. Ancak FOMPEYDİE (3) ince tabaka kromatografisi yardımı ile adı geçen deriveleri ayırmayı başarmıştır. Ama, ayırma işlemi aynı yürütücü sistemi ile kolona uygulandığında ise ayrılmanın olmadı̆̆ı gözlenmiştir.

Biz çalışmalarımızda FOMPEYDİE'nin ince tabakada başardığı ayırmayı kolon kromatografisinde de gerçekleştirmeyi amaçladık. Bu nedenle değişik adsorbanlar ve yürütücü sistemlerini denedik. Araştırmalarımız sonucunda silikajel ile hazırlanmış kolonda aynı ayırmayı başardık.

\section{DENEYSEL KISIM}

Kullandığımız kolon ile ilgili özellikler aşağıdadır:

Kolon uzunluğu: $19 \mathrm{~cm}$

Kolon çap1: $16 \mathrm{~mm}$

Yürütücü sistemi: Toluen/asetik asit (9:1)

Yürütücü hacmi: $100 \mathrm{ml}$

Adsorban: Silikajel (230 mesh) Merck

Damlatma hizı: 3 damla/dk

Kolon materyali, $20 \mathrm{~g}$ silikajelin $40 \mathrm{ml}$ yürütücü sistemi içerisindeki süspansiyonu olacak şekilde hazırlanır. Ayrılması istenen deriveleri içeren, eosin de aynı yürütücü sistemi içerisinde çözülerek hazırlanır ve kolona tatbik edilir. Yukarıda belirtilen hızda elüsyon yapılır ve bu işleme yaklaşık 12 saat kadar devam edilir. Sürenin sonunda gözle izlenebilen renkli deriveler birbirlerinden iyice ayrılır. Sonra kolon materyali alt ucundan itilerek adsorbanın üst uçtan dışarı akması sağlanır ve deriveleri içeren renkli halkalar tek tek ayrılarak değişik kaplara konulur. Daha sonra bu parçalar etanol ile ekstre edilerek kolon materyalinden ayrılır. Ekstraksiyonda etanol kullanılmasının nedeni bileşiklerin bu çözücüde çok yüksek bir çözünürlüğe sahip olmalarıdır.

Çalışmamızda 12 saatlik elüzyon sonucunda floreseinin başlangıç noktasında kaldığı, buna karşılık mono-, di-, tri ve tetrabromo floresein derivelerinin sırasıyla Rf $0.13,0.38,0.54$ ve 0.87 ile birbirlerinden ayrıldı̆̆ı gözlendi (Şek. 1). 


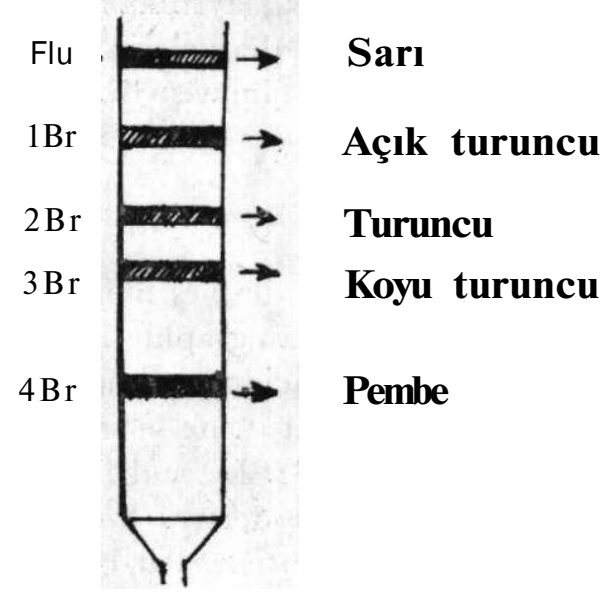

Şek. 1. Ayrılan derivelerin renkleri

Etanol ile ekstre edilen bu bromlu bileşiklerin saflıkları ince tabaka kromatografisi ile (3) kontrol edildi. Elde edilen kromatograma göre derivelerin saf olarak ayrılmış oldukları görüldü.

\section{T A R T I Ş M A}

Kolon kromatografisi ile başardı̆̆ımız bu ayırma işleminin tek dezavantajı eosin ve diğer bromlu floresein bileşiklerinin yürütücü sistemi içerisindeki çözünürlüklerinin yüksek olmayışıdır (örneğin eosin için çözünürlük $0.3 \mathrm{mg} / \mathrm{ml}$ dir). Dolayısı ile verim düşük olmaktadır; örneğin eosin Gelblich (Merck) ile yaptığımız çalışmalar sonucunda, ki içerisinde \% 63 eosin \% 36 tribromo floresein ve \% 1 oranında da yapısı henüz bilinmeyen pembe renkli bir bileşik bulunmaktadir (10.7 mg ticari numuneden hareketle $6.3 \mathrm{mg}$ eosin ve $3.4 \mathrm{mg}$ tribromo floresein elde edebildik). Ama, buna karşılık bileşikler çok saf olarak elde edilebilmektedirler. Ayrıca derivelerin birbirlerinden farklı olan renkleri ayrılmanın gözle izlenmesine imkan tanımakta, böylece bir revelatöre gerek duyulmamaktadır.

\section{ÖZET}

Günümüze kadar yalnızca ince tabaka kromatografisi ile ayrılabilen floreseinin mono-, di-, tri- ve tetrabromo derivelerinin kolonda, adsorban olarak silikajel ve yürütücü sistemi olarak ta 
Toluen/Asetik asit (9:1) kullanarak ayrılmaları gerçekleştirildi. Karşılaşılan tek güçlük bromlu bu derivelerin yürütücü sistemi içerisindeki çözünürlüklerinin yüksek olmayışıydı. Bunun sonucunda da verim düşük oldu.

\section{RES U ME}

Nous avons réussi de séparer des dérivés mono-, di-, tri- et tétrabromés de la fluorescein par chromatographic en colonne utilisant silicagel comme support et Toluene/acide acétique (9:1) comme système d'élution que jusqu'à maintenant üs ne se sont séparés que par chromatographic sur couche mince (3). Le seul handicap que nou? nous sommes rencontre c'est que ces derives bromes n'ont pas de grande solubilité dans le système d'élution. Par consequence, le rendement n'est pas très élevé.

\section{LÍTERAT ÜR}

1- Orndorff, W. R., Hemmer, A. J., J. Am. Chem. Soc. 49 1272-80 (1929)

2- Graichen, C., Molitor, J. C., J. Ass. Off Agric. Chem. 42 149-61 (1959)

3- Fompeydie. D., Thèse, Université Rene Descartes de Paris (1978) 